Tamil Nadu, India

kamala.thiagarajan@gmail.com Cite this as: BMJ 2021;373:n997 http://dx.doi.org/10.1136/bmj.n997 Published: 20 April 2021

\section{COVID-19 VACCINES}

\section{What do we know about India's Covaxin vaccine?}

\section{India has rapidly approved and rolled out Covaxin, its own covid-19 vaccine. Kamala Thiagarajan} examines what we know so far.

\section{Kamala Thiagarajan freelance journalist}

\section{Who developed Covaxin?}

Covaxin was developed by Indian pharmaceutical company Bharat Biotech in collaboration with the Indian Council of Medical Research, a government funded biomedical research institute, and its subsidiary the National Institute of Virology.

Bharat Biotech has brought to market 16 original vaccines, including for rotavirus, hepatitis B, Zika virus, and chikungunya. ${ }^{1}$ The company reportedly spent \$6o-\$7om (£43-€50m; €50-€58m) developing Covaxin. $^{2}$

\section{How does Covaxin work?}

The vaccine is similar to CoronaVac (the Chinese vaccine developed by Sinovac) ${ }^{3}$ in that it uses a complete infective SARS-CoV-2 viral particle consisting of RNA surrounded by a protein shell, but modified so that it cannot replicate. ${ }^{4}$

Covaxin comes as a two-dose regimen, recommended to be taken 28 days apart.

\section{What peer reviewed data are available for the vaccine?}

Covaxin's phase I trial to assess safety and immunogenicity is published. ${ }^{5}$ All 375 subjects who received the vaccine had notably elevated antibody response. 6

The phase II trial result has not yet been published in a peer reviewed journal, but a preprint has been posted on MedRxiv. ${ }^{7}$ The provisional data indicate enhanced immune response and tolerable safety outcomes.

Since November, 25800 participants have been enrolled in ongoing phase III trials. Bharat Biotech released interim efficacy data on 3 March 2021, which showed a clinical efficacy of $81 \%{ }^{8}$

\section{Why did India choose to develop its own vaccine?}

With the goal of vaccinating 300 million people every quarter, costs are mounting. Doctors say it may take two years to vaccinate the entire population. ${ }^{9}$ The first round of immunisations has been subsidised by the government and is free for India's 30 million health workers, older people, and frontline workers. ${ }^{10}$

Each dose of Covaxin costs 295 rupees ( $€ 2.93$ versus $£ 19-£ 28$ for the Moderna vaccine ${ }^{11}$ and $£ 26.70$ for the Pfizer/BioNTech ${ }^{12}$ ). Moreover, Bharat Biotech is providing the first 1.65 million doses at no cost to the government. This makes the Indian vaccine the cheapest purchased by any country in the world at 206 rupees per shot for the 5.5 million doses the government currently has on order. The government has capped the price of the vaccine sold in the private market, with private hospitals able to charge up to 250 rupees. ${ }^{13}$

Covaxin does not require storage at sub-zero temperatures, which would be hard to maintain in India's climate and with the frequent power cuts in rural areas. Covaxin is available in multi-dose vials and is stable at the $2-8^{\circ} \mathrm{C}$ that ordinary refrigeration can achieve.

Bharat Biotech says it has a stockpile of 20 million doses of Covaxin for India and is in the process of manufacturing 700 million doses at its four facilities in two cities by the end of the year. It says it can provide 300 million shots annually.

\section{When was Covaxin approved for public use?}

The Central Drugs and Standards Committee (CDSCO), India's top drug regulator, issued an emergency approval for Covaxin on 3 January 2021, even though phase III clinical trials are still ongoing and phase II studies are unpublished. ${ }^{14}$ The regulator cited the need for protection against the potential spread of the UK variant. No peer reviewed evidence is available to show that the vaccine would be effective against this strain, although a preprint indicates promising results. ${ }^{15}$

The vaccine is currently being administered in India to people over 60 and those over 45 with comorbidities, as well as to health workers. At the time of writing, India had administered more than 100 million vaccinations, although it is not clear how many are Covaxin (most are Covishield, India's version of the Oxford-AstraZeneca vaccine manufactured in Pune by the Serum Institute of India).

\section{Which other countries have ordered Covaxin? \\ Bharat Biotech has signed deals with Ocugen, a US based biopharmaceutical company, to produce the vaccine for the US market, and Precisa Medicamentos to supply to Brazil, pending regulatory approval there. \\ How has Covaxin been received by the medical community?}

The emergency approval before phase III trials were completed triggered widespread criticism from the scientific community in India. ${ }^{16}$ 
With nearly 14 million coronavirus infections at the time of writing, India has the second highest number of reported cases globally after the US, but the approval came at a time when cases were dropping.

The CDSCO said the vaccine had been approved for "restricted use in an emergency situation" and that it would be deployed in a “clinical trial mode.” This vague terminology, with no official clarification, has left doctors and scientists puzzled, though one doctor The $B M J$ spoke to said it implied that safety data would be collected.

The All India People's Science Network, which represents numerous scientific organisations, described the approval of Covaxin as "hasty," while the All India Drug Action Network, a group of non-government organisations working to increase access to essential medicines, said it was "shocked" and "baffled" by the decision. In the interest of "public welfare and transparency" the group urged regulators to make the data public.

To compound this anxiety, one participant in the phase III trials died. The hospital at which the trial took place, the People's College of Medical Sciences and Research Centre in Bhopal, has been accused of not following proper procedures while screening candidates for the trials.

However, 45 doctors-including two former directors of the All India Institute of Medical Science-labelled the criticisms of Covaxin as "irresponsible." ${ }^{17}$ They called the vaccine India's "gift to humanity."

Competing interests: I have read and understood the BMJ policy on declaration of interests and have no relevant interests to declare.

Provenance and peer review: commissioned; externally peer reviewed.

1 Bharat Biotech. https://www.bharatbiotech.com/exports.html

2 Kay C. 'Sometimes I get goosebumps,' says Bharat Biotech MD as firm preparing for Covaxin rollout. Bloomberg2020. https://www.livemint.com/science/health/indian-covid-vaccine-makerbharat-biotech-readies-for-covaxin-rollout-11608625913405.html

3 Baraniuk C. What do we know about China's covid-19 vaccines?BMJ2021;373:n912. doi: 10.1136/bmj.n912 pmid: 33836994

4 Robertson S. India's whole-virion inactivated SARS-CoV-2 vaccine shows promise. News Medical Life Sciences 2020. https://www.news-medical.net/news/20200913/Indias-whole-virion-inactivated-SARS-CoV-2-vaccine-shows-promise.aspx

5 Ella R, Vadrevu KM, Jogdand H, etal. Safety and immunogenicity of an inactivated SARS-CoV-2 vaccine, BBV152: a double-blind, randomised, phase 1 trial. Lancet Infec Dis, 2021, doi: 10.1016/S1473-3099(20)30942-7.

6 Adjuvant alhydroxiquim-II to boost immune response of Covaxin. The Hindu 2020. https://www.thehindu.com/business/Industry/adjuvant-alhydroxiquim-ii-to-boost-immune-response-of-covaxin/article32771112.ece

7 Ella R, Reddy S, Jogdand H, etal. Safety and immunogenicity clinical trial of an inactivated SARS-CoV-2 vaccine, BBV152 (a phase 2, double-blind, randomised controlled trial) and the persistence of immune responses from a phase 1 follow-up report. MedRxiv [preprint].2020. https://www.medrxiv.org/content/10.1101/2020.12.21.20248643v1

8 Bharat Biotech. Bharat Biotech announces phase 3 results of COVAXIN: India's first COVID-19 vaccine demonstrates interim clinical efficacy of $81 \%$. 2021. https://www.bharatbiotech.com/images/press/covaxin-phase3-efficacy-results.pdf

9 Sharma N. Long road ahead: vaccinating India will take at least two years, say doctors. Economic Times 2020. https://economictimes.indiatimes.com/industry/healthcare/biotech/healthcare/vaccinating-india-will-take-at-least-2-years-say-doctors/articleshow/77095695.cms

10 Dey S. Covid vaccine to be free for 'most prioritised' beneficiaries: Vardhan. Times of India 2021 https://timesofindia.indiatimes.com/india/covid-vaccine-to-be-free-for-most-prioritised-beneficiaries-vardhan/articleshow/80077154.cms

11 Moderna to charge Rs 1855-Rs 2755 per dose for COVID-19 vaccine, says CEO. DNA India 2021. https://www.dnaindia.com/world/report-moderna-to-charge-rs-1855-rs-2755-per-dose-for-covid19-vaccine-says-ceo-2857843

12 Pfizer vaccine's price may be throwing off Indian government, report says. The Wire 2021. https://science.thewire.in/health/pfizer-vaccines-price-may-be-throwing-off-indian-governmentreport-says/

13 Covid-19 vaccine: private hospitals can charge up to Rs 250 per dose. Economic Times2021. https://economictimes.indiatimes.com/news/politics-and-nation/covid-19-vaccine-private-hospitalscan-charge-up-to-rs-250-per-dose/articleshow/81246140.cms?from=mdr
14 Thiagarajan K. Covid-19: India is at centre of global vaccine manufacturing, but opacity threatens public trust. BMJ2021;372:n196. doi: 10.1136/bmj.n196 pmid: 33509837

15 Sapkal GN, Yadav PD, Ella R, etal. Neutralization of UK-variant VUI-202012/01 with COVAXIN vaccinated human serum. bioRxriv [preprint]2021. https://www.biorxiv.org/content/10.1101/2021.01.26.426986v1

16 Scientists urge govt to release Covaxin phase 3 trial data before rollout. The Wire 2021. https://science.thewire.in/health/bharat-biotech-covaxin-vaccine-data/

17 Irresponsible statements of vested interests: experts slam critics of India's approval process for COVID vaccines. New Indian Express 2021. https://www.newindianexpress.com/nation/2021/jan/15/irresponsible-statements-of-vested-interests-experts-slams-critics-of-indiasapproval-process-for-2250407.html 